\title{
THE EFFECT OF ABDOMINAL STRETCHING EXERCISE ON THE INTENSITY OF DYSMENORRHEA
}

\author{
Nurfitri1 ${ }^{1}$ Andi Rizky Amaliah², Nour Sriyanah ${ }^{3}$ \\ Email : ns.nurfitri@gmail.com \\ 1,2,3Sekolah Tinggi Ilmu Kesehatan Makassar, Indonesia
}

ARTICLE INFO

Keywords:

Dysmenorrhea; Abdominal; Stretching; Exercise

intensity of dysmenorrhea in adolescent girl students at the State Senior High School. Method: This study was a quasi-experiment using a pretest-posttest research design with a total of the study samples were 40 respondents by purposive sampling technique. Assessment of the effect of abdominal stretching exercise was carried out before and after 8 abdominal stretching exercise trials. The gathered data were processed and analyzed using the paired samples t-test using IBM SPSS statistical software, version 26. Results of the present study demonstrated a significant effect of abdominal stretching exercise on the reduction of dysmenorrheal intensity $(P<0.05)$. Discussion The effects of high-intensity exercise on progesterone, prostaglandin metabolites (13,14-dihydro-15-keto-prostaglandin F2 alpha (KDPGF2 $\alpha$ ), TNF- $\alpha$, and pain intensity were found to be increased in progesterone and decreased KDPGF2 $\alpha, T N F-\alpha$, and pain intensity after exercise high intensity is relative without exercise. The mechanisms underlying high-intensity exercise-induced analgesia use hormones (progesterone) and cytokine-mediated mechanisms to reduce pain associated with primary dysmenorrhea. Conclusion: abdominal stretching exercise significantly reduced the intensity of primary dysmenorrhea in adolescent girl students. Therefore, abdominal stretching exercise is beneficial to be used as an alternative method in reducing intensity of dysmenorrhea in adolescent girls.

\section{ABSTRAK}

Tujuan: untuk mengetahui pengaruh latihan abdominal stretching terhadap penurunan intensitas dismenorea pada remaja putri siswi SMA Negeri. Metode: Penelitian ini merupakan penelitian eksperimen semu dengan menggunakan desain penelitian pretest-posttest dengan jumlah sampel penelitian sebanyak 40 responden dengan teknik purposive sampling. Penilaian pengaruh latihan peregangan perut dilakukan sebelum dan sesudah 8 kali percobaan latihan peregangan perut. Data yang terkumpul diolah dan dianalisis menggunakan uji t sampel berpasangan menggunakan perangkat lunak statistik IBM SPSS, versi 26. Hasil penelitian ini menunjukkan pengaruh yang signifikan dari latihan peregangan perut terhadap penurunan intensitas dismenore $(P<0,05)$. Diskusi Efek latihan intensitas tinggi pada progesteron, metabolit prostaglandin $(13,14$ dihydro-15-keto-prostaglandin F2 alpha (KDPGF2 $\alpha$ ), TNF- $\alpha$, dan intensitas nyeri ditemukan peningkatan progesteron dan penurunan $\operatorname{KDPGF} 2 \alpha$, TNF $-\alpha$, dan intensitas nyeri setelah latihan intensitas tinggi adalah relatif tanpa latihan. Mekanisme yang mendasari analgesia yang diinduksi latihan intensitas tinggi menggunakan hormon (progesteron) dan mekanisme yang dimediasi sitokin untuk mengurangi rasa sakit yang terkait dengan dismenore primer. Intensitas dismenore primer pada siswi remaja putri, oleh karena itu latihan peregangan perut bermanfaat untuk dijadikan sebagai metode alternatif dalam menurunkan intensitas dismenorea pada remaja putri.

\section{Introduction}

Dysmenorrhea or painful menstruation is the most common menstrual symptom among adolescent and young women. Most adolescents experience primary dysmenorrhea, which is defined as painful menstruation without pelvic pathology (1). The accurate prevalence of dysmenorrhea is difficult to determine since the various diagnostic criteria and the subjective nature of symptoms (2).

The prevalence of dysmenorrhea in Georgea (52.07\%) (3), in Ghana is (68.1\%) (4), in Manipur $(76.0 \%)(5)$, in India (84.2\%) (6), in Iran (89.1\%) (7), in Turkey $(72,7 \%)(8)$, in central Jakarta (87.5\%) (9), in Manado (98.5\%) (10), and in Makassar (53.9\%) (11).

Dysmenorrhea has a negative impact on physical activity (22.5\%) (4), affects on educational performance, $(69.78 \%)$ absence from school due to the pain (3), decreasing concentration during class (27.9\%) (4), poor test scores, and poor interpersonal relationships (5). 
Optional management for primary dysmenorrhea includes nonsteroidal anti-inflammatory drugs and hormonal contraceptives, topical heat, exercise, and nutritional supplementation (12). Exercise shows the greatest effect compared to heat therapy and acupressure in reducing dysmenorrhea and as a potential alternative to analgesics (13). The results of a systematic review found that exercise therapy confirmed some evidence of pain reduction in primary dysmenorrhea (14).

Regular stretching exercises that combined with regular menstrual treatments are effective in reducing the intensity of low back pain in primary dysmenorrhea and premenstrual symptoms (15);(16). Stretching exercises for 8 weeks ( 2 times in a day) which carried out at home reduce the intensity and duration of pain and are easy to do autonomously (17).

The research from Aboushady \& El-saidy in 2016 (15) reported that stretching exercise can reduce premenstrual symptoms, namely reduced fatigue (Pre $50.0 \%$, post $25.0 \%$ ), headaches (pre $35.0 \%$, post $20.0 \%$ ), changes mood (pre $67.5 \%$, post $25.0 \%$ ), constipation (pre $10.0 \%$, post $7.5 \%$ ), and excessive sweating (pre $10.0 \%$, post $7.5 \%$ ) and pain intensity weight (pre $37.5 \%$, post $12.5 \%)$.

One of the stretching exercises is the abdominal stretching exercise which is useful for increasing abdominal muscle strength, abdominal flexibility and endurance in particular circumstances, as well as relaxation of breathing to relax, releasing tension and increasing lung ventilation so it can reduce the scale of dysmenorrhea (18). Wong states that exercises by moving the pelvis, knee-chest positions and chest breathing exercises can be helpful for reducing dysmenorrhea (19).

Dysmenorrhea intensity pain scale can be measured using the Numerical Rating Scale (NRS) which is the most effective scale used when assessing pain intensity before and after intervention (20). The NRS scale is considered simple and easy to understand, especially for assessing acute pain (21).

The pain intensity in primary dysmenorrhea decreases after given the abdominal stretching exercises (22), abdominal stretching exercises can trigger the endhorphins (natural opiates) which are able to reduce pain (23). The objective of this study was to determine the effect of abdominal stretching exercise on the intensity of dysmenorrhea in high school students.

\section{Methods}

\section{Study design}

This was quasi-experimental design research with pretest-posttest with a comparison group design.

\section{Respondent}

The respondents in this study were high school students at SMA Neg. 8 East Luwu, SMA Neg. 9 Maros and SMA Neg. 15 Makassar. The total number of respondents was 68 respondents which is divided into 40 respondents for the intervention group and 28 respondents for the control group. The inclusion criteria in this study were high school students who had menstruation, had regular menstruation and had dysmenorrhoea. The exclusion criteria were the high school students who had gynecological diseases and were pregnant.

\section{Instrument}

The instrument employed to assess the respondents' pain scale was the Numeric Rating Scale (NRS). It uses the scale 0-10 to describe the quality of pain., 0 means no pain, 1-3 are mild pain, 4-6 moderate pain, 7-9 are controlled severe pain, and 10 for uncontrolled severe pain.

\section{Intervention}

During this study, it was still in a COVID-19 pandemic situation, so we had to implement a health protocol on its implementation. Each student was given mask and taught to wash their hands in 6 steps before and after the exercise using a handsanitizer, and setting the students' 
distance in 2 meters. There were maximum 15 students who attend training at each meeting. The direct meeting by implementing the health protocol had received permission from the school and it is not possible practicing virtually due to network problems in some of the respondents' place.

On the intervention group doing abdominal stretching exercises 2 times a week for 4 weeks. The abdominal stretching exercise is performed 8 times with 30 minutes maximum duration per exercise. Pain scale assessment was done before the abdominal stretching exercise and after 8 times of the abdominal stretching exercise. Meanwhile, the control group was taught abdominal stretching exercises after the end of the study.

\section{Data colection}

This research was conducted on 29 August - 29 September 2020 by researchers. Before doing the exercise, we distributed a questionnaire which containing data on the characteristics of the respondent and the pain scale using the Numeric Rating Scale (NRS) instrument. This questionnaire was made in google form. Each respondent in the intervention group filled out a questionnaire in google form before training and after 8 exercises. Whereas in the control group the filling was carried out when having menstruation in the month and menstruation in the following month.

\section{Data analysis}

The obtained data were processed using SPSS 26. Univariate analysis including demographic characteristics namely age and health status, age at first menstruation, length of menstruation, pre and post intervention pain categories, pre and post intervention pain scales, and activities carried out when experiencing dysmenorrhea. Bivariate analysis using paired $t$ test to see changes in the pre and post pain scale in the intervention group and the control group. The paired t test was used in the intervention group after transforming the data, so the distribution of the intervention group data became normal and to see the difference in pain scale on the intervention group and the control group using the independent $\mathrm{T}$ test.

\section{Ethical consideration}

Each respondent signed informed consent before data collection. Before signing the informed consent, the researchers first explained the purpose of the study and the confidentiality of the data

\section{Results}

\section{Characteristics of Respondents}

The majority of age in the intervention group was 16 years old, experienced their first menstruation at 14 years old, for 7 days each cycle, the maximum pain scale before doing abdominal stretching exercise was 10 and after the exercise was 9, the activity carried out when experiencing pain was sleeping. On the control group, the majority were 16 years old, the first menstruation was at 16 years old, for 6 days each menstrual cycle, the maximum pain scale was also 10 , the activity carried out when experiencing pain was sleeping.

Table 1. Demographic characteristics and health status of respondents on the intervention group and the control group

\begin{tabular}{lcc}
\hline \multicolumn{1}{c}{ Characteristics } & $\begin{array}{c}\text { Intervention } \\
(\mathbf{n = 4 0 )}\end{array}$ & $\begin{array}{c}\text { Control } \\
(\mathbf{n = 2 8})\end{array}$ \\
\hline $\begin{array}{l}\text { School } \\
\text { SMA Neg. 8 Luwu Timur }\end{array}$ & $20(26.0 \%)$ & $10(13.0 \%)$ \\
SMA Neg. 9 Maros & $12(15.6 \%)$ & $10(13.0 \%)$ \\
SMA Neg 15 Makassar & $8(10.4 \%)$ & $8(10.4 \%)$ \\
Age (years old) & & $1(2.5 \%)$ \\
13 & $0(0 \%)$ & $5(12.5 \%)$ \\
\hline 15 & $13(32.5 \%)$ & \\
\hline
\end{tabular}




\begin{tabular}{|c|c|c|}
\hline 16 & $16(40.0 \%)$ & $18(45.0 \%)$ \\
\hline 17 & $9(22.5 \%)$ & $2(5.0 \%)$ \\
\hline 18 & $2(5.0 \%)$ & $0(0 \%)$ \\
\hline 19 & $0(0 \%)$ & $2(5.0 \%)$ \\
\hline Age on first menstruation (ye & & \\
\hline old) & $1(2.5 \%)$ & $0(0 \%)$ \\
\hline 11 & $5(12.5 \%)$ & $0(0 \%)$ \\
\hline 12 & $14(35.0 \%)$ & $1(2.5 \%)$ \\
\hline 13 & $18(45.0 \%)$ & $0(0 \%)$ \\
\hline 14 & $0(0 \%)$ & $5(12.5 \%)$ \\
\hline 15 & $2(5.0 \%)$ & $18(45.0 \%)$ \\
\hline 16 & $0(0 \%)$ & $2(5.0 \%)$ \\
\hline 17 & $0(0 \%)$ & $2(5.0 \%)$ \\
\hline 19 & & \\
\hline Length of mentruation (days) & $1(2.5 \%)$ & $0(0 \%)$ \\
\hline 3 & $2(5.0 \%)$ & $1(2.5 \%)$ \\
\hline 4 & $0(0 \%)$ & $4(10.0 \%)$ \\
\hline 5 & $2(5.0 \%)$ & $12(30.0 \%)$ \\
\hline 6 & $33(82.5 \%)$ & $8(20.0 \%)$ \\
\hline 7 & $2(5.0 \%)$ & $2(5.0 \%)$ \\
\hline 8 & $0(0 \%)$ & $1(2.5 \%)$ \\
\hline 10 & & \\
\hline Pre-intervention pain catego & & \\
\hline (NRS scale) & $13(32.5 \%)$ & $5(12.5 \%)$ \\
\hline Mild & $22(55.0 \%)$ & $15(37.5 \%)$ \\
\hline Moderate & $5(12.5 \%)$ & $8(28.6 \%)$ \\
\hline Severe & & \\
\hline Post intervention pain & & \\
\hline category (NRS scale) & $29(72.5 \%)$ & $6(15.0 \%)$ \\
\hline Mild & $7(17.5 \%)$ & $18(45.0 \%)$ \\
\hline Moderate & $4(10 \%)$ & $4(14.3 \%)$ \\
\hline Severe & & \\
\hline $\begin{array}{l}\text { Pre intervention dysmenorrh } \\
\text { pain scale (NRS scale) (mean }\end{array}$ & & \\
\hline SD) & $4.39 \pm 1.5$ & $5.43 \pm 2.2$ \\
\hline Min - Max & $2-10$ & $1-10$ \\
\hline $\begin{array}{l}\text { Post intervention dysmenorr } \\
\text { pain scale }\end{array}$ & & \\
\hline (NRS scale) (mean \pm SD) & $3.04 \pm 1.9$ & $5.0 \pm 2.0$ \\
\hline Min - Max & $1-9$ & $1-10$ \\
\hline Activity during dysmenorrhe & & \\
\hline Sleeping & & \\
\hline Applying eucalyptus oil & 27 (67.5\%) & $21(52.5 \%)$ \\
\hline Ignoring & $9(22.5 \%)$ & $0(0 \%)$ \\
\hline Taking a pain reliever & $3(7.5 \%)$ & $0(0 \%)$ \\
\hline Others & $0(0 \%)$ & $5(12.5 \%)$ \\
\hline & $1(2.5 \%)$ & $2(5.0 \%)$ \\
\hline
\end{tabular}

Table 1 shows the average school origin of the respondents in the intervention group, namely SMA Neg. 8 East Luwu (n: 20, 26.0\%), SMA Neg. 9 Maros (n: 12, 15.6\%), and SMA Neg 15 Makassar (n: 8, 10.4\%), the average age is 16 years (n:16, 40.0\%), the average age at first menstruation is 14 years ( $\mathrm{n}: 18,45.0 \%$ ), the average length of menstruation in one period is 7 days (n: $33,82.5 \%$ ), the average pre-intervention pain category is the mild category $13(32.5 \%)$, moderate category $22(55.0 \%)$, and severe category $5(12.5 \%)$, the average category of pain before the intervention was a mild category 29 (72.5\%), moderate category 7 (17.5\%), and severe category $4(10 \%)$, the average pain scale post intervention $4.39 \pm 1.5(2-10)$, the average pain scale after intervention was $3.04 \pm 1.9(1-9)$, and activities carried out while experiencing dysmenorrhea, namely sleeping (n: 27, 67.5\%). And in the control group, the average school origin of the respondent is SMA Neg. 8 East Luwu (n: 10, 13.0\%), SMA Neg. 9 Maros (n: 10, 
13.0\%), and SMA Neg 15 Makassar (n: 8, 10.4\%), 16 years (n: 18, 45.0\%), the average age at first menstruation was 16 years (n: $18,45.0 \%$ ), the average length of menstruation in one period is 6 days (n: $12,30.0 \%$ ), 7 days (n: $8,20.0 \%$ ), the average pre pain category is the mild category (n: $5,12.5 \%)$, moderate category (n:15, 37.5\%), and severe category (n: $8,28.6 \%)$, the average post pain category is the mild category (n: $6,15.0 \%)$, moderate category $(n: 18,45.0 \%)$, and severe category (n: $4,14.3 \%$ ), the average pre pain scale was $5.43 \pm 2.2(1-10)$, the average post pain scale was $5.0 \pm 2.0(1-10)$, and activity What to do when experiencing dysmenorrhea is sleeping (n: $21,52.5 \%$ )

Table 2. Difference in mean dysmenorrhea pain scale before and after abdominal stretching exercise

\begin{tabular}{|c|c|c|c|c|}
\hline \multirow[t]{2}{*}{ Variable } & Pretest & Posttest & IK & $\mathrm{P}$ \\
\hline & $\begin{array}{l}\text { Mean } \\
\text { (SD) }\end{array}$ & $\begin{array}{l}\text { Mean } \\
\text { (SD) }\end{array}$ & $95 \%$ & Score \\
\hline $\begin{array}{l}\text { Interventional } \\
\text { dysmenorrhea pain } \\
\text { scale }(n=40)\end{array}$ & $\begin{array}{l}0.63 \\
(0.151)\end{array}$ & $\begin{array}{l}0.39 \\
(0.27)\end{array}$ & $\begin{array}{l}0.16- \\
0.31\end{array}$ & $0.00^{* a}$ \\
\hline Control & 5.43 & 5.00 & - & $0.16^{\mathrm{a}}$ \\
\hline $\begin{aligned}(\mathrm{n}=28) & p \text {-value }\end{aligned}$ & $(2.23)$ & $(2.07)$ & $\begin{array}{l}0.182- \\
1.03\end{array}$ & $0.00^{* b}$ \\
\hline
\end{tabular}

${ }^{*}$ significance at $<0.05$ । a paired sample t-testl bindependent t-test

Table 2 reports in the intervention group of 40 respondents showed that the average result before abdominal stretching exercise was $0.63(0.151)$, while the mean score after abdominal stretching exercise was $0.39(0.27)$. These results showed that the pain scale decreased before and after the abdominal stretching exercise with $\mathrm{p}$ value $=0.00$, it means there is an effect of abdominal stretching exercise on the intensity of menstrual pain (dysmenorrhea). It is in contrast with the control group of 28 respondents, which showed the mean pre on the control group was 5.43 (2.23), while the post mean was 5.00 (2.07). The results reported that the pain scale experienced a slight decrease between pre and post on the control group with $p$ value $=$ 0.16 , it means that there was no effect between pre and post on the control group on the intensity of menstrual pain (dysmenorrhea). The difference in the mean pain scale on the intervention group was 4.58 lower than the control group. The results of the analysis using the independent $\mathrm{t}$ test obtained $\mathrm{p}$ value $=0.00$, this means that there is a difference between the dysmenorrhea pain scale with abdominal stretching exercise and the dysmenorrhea pain scale without abdominal stretching exercise.

\section{Discussion}

Abdominal stretching exercises were performed 2 times a week for 4 weeks. The pain scale was measured using the NRS scale before the abdominal stretching exercises and after abdominal stretching exercises. From the pain scale measurement results, it was found that the mean of pain scale decreased before and after the abdominal stretching exercise. The control group also experienced a decrease in the mean of pain scale which is smaller than the intervention group who did abdominal stretching exercise. Abdominal stretching exercise is recommended as a dysmenorrhea intervention that affects adolescent. This exercise can be a new routine for young women since it is very beneficial for them (24).

The research by Motahari-Tabari, Shirvani, \& Alipour (25) found that stretching exercises were as effective as mefenamic acid in the treatment of primary dysmenorrhea. The results of their research indicated that the effect of exercise in relieving dysmenorrhoea increased over time. Research by Ortiz et al., (26) reports that muscle strengthening, stretching and relaxation techniques are effective in reducing dysmenorrhea symptoms when done regularly. Armor et al., (13) stated that exercise showed a large effect, whereas acupressure and heat therapy showed moderate effects in reducing menstrual pain compared to no treatment. Both exercise and heat therapy are potential alternatives to analgesic treatment. High-intensity exercise is effective in reducing the quality and intensity of pain in women with primary dysmenorrhea (27). 
The pathogenesis of primary dysmenorrhea is an increase in the level of uterine prostaglandins. The etiological study reports that prostaglandin production is controlled by the sex hormone progesterone, with prostaglandins and progesterone shows an inverse relationship (ie, increasing progesterone levels decreasing prostaglandin levels). Pro-inflammatory cytokines (interleukin-6 [IL-6] and tumor necrosis factor-alpha [TNF- $\alpha]$ ) are also involved in the pathogenesis of primary dysmenorrhea. High-intensity of exercise is effective in reducing the quality and intensity of pain on women with primary dysmenorrhea. The effects of highintensity exercise on progesterone, prostaglandin metabolites (13,14-dihydro-15-ketoprostaglandin $\mathrm{F} 2$ alpha (KDPGF2 $\alpha$ ), TNF- $\alpha$, and pain intensity were found to be increased in progesterone and decreased KDPGF $2 \alpha$, TNF- $\alpha$, and pain intensity after exercise high intensity is relative without exercise. The mechanisms underlying high-intensity exercise-induced analgesia use hormones (progesterone) and cytokine-mediated mechanisms to reduce pain associated with primary dysmenorrhea (27); (28).

\section{Conclusion}

Abdominal stretching exercise significantly reduced the intensity of primary dysmenorrhea in adolescent girl students. Therefore, abdominal stretching exercise is beneficial to be used as an alternative method in reducing intensity of dysmenorrhea in adolescent girls.

\section{References}

1. Klebanoff MA. ACOG Committee Opinion No. 739: The Late-Career ObstetricianGynecologist. Obstet Gynecol [Internet]. 2018;132(6). Available from: https://journals.lww.com/greenjournal/Fulltext/2018/12000/ACOG_Committee_Opinion_ No_739__The_Late_Career.32.aspx

2. Sanctis V, Soliman A, Bernasconi S, Bianchin L, Bona G, Bozzola M, et al. Primary Dysmenorrhea in Adolescents: Prevalence, Impact and Recent Knowledge. Pediatr Endocr Rev. 2015 Dec 1;13:465.

3. Gagua T, Tkeshelashvili B, Gagua D. Primary dysmenorrhea: Prevalence in adolescent population of Tbilisi, Georgia and risk factors. J Turkish Ger Gynecol Assoc. 2012 Sep 1;13:162-8.

4. Acheampong K, Baffour Awuah D, Ganu D, Stella A, Pan X, Kaminga A, et al. Prevalence and Predictors of Dysmenorrhea, Its Effect, and Coping Mechanisms among Adolescents in Shai Osudoku District, Ghana. Obstet Gynecol Int. 2019 May 20;2019:1-7.

5. Kumar Ks, Konjengbam S, Devi H. Dysmenorrhea among higher secondary schoolgirls of Imphal West district, Manipur: A cross-sectional study. J Med Soc. 2016 Jan 1;30:38.

6. Kural M, Noor N, Pandit D, Joshi T, Patil A. Menstrual characteristics and prevalence of dysmenorrhea in college going girls. J Fam Med Prim care. 2015 Jul 1;4:426-31.

7. Habibi N, Huang M, Gan WY, Rejali Z, Safavi S. Prevalence of Primary Dysmenorrhea and Factors Associated with Its Intensity Among Undergraduate Students: A Cross-Sectional Study. Pain Manag Nurs. 2015 Aug 1;

8. Unsal A, Ayranci U, Tozun M, Arslan G, Calik E. Prevalence of dysmenorrhea and its effect on quality of life among a group of female university students. Ups J Med Sci. 2010 May 1;115:138-45.

9. Juniar D. Epidemiology of Dysmenorrhea among Female Adolescents in Central Jakarta. Makara J Heal Res. 2015;19:21-6.

10. Sirait DSO. Faktor-faktor Yang Berhubungan dengan Kejadian Dismenore pada Siswi SMA Negeri 2 Medan [Internet]. Universitas Sumatera Utara. Universitas Sumatera Utara; 2015 [cited 2021 Jul 6]. Available from: https://onesearch.id/Record/IOS1029.article-8583

11. Utami ANR, Ansar J, Sidik D. Faktor-faktor Yang Berhubungan dengan Kejadian Dismenorea Pada Remaja Putri Di SMAN Kahu Kabupaten Bone. In 2013.

12. Osayande A, Mehulic S. Diagnosis and Initial Management of Dysmenorrhea. Am Fam Physician. 2014 Mar 1;89:341-6.

13. Armour M, Smith CA, Steel KA, Macmillan F. The effectiveness of self-care and lifestyle interventions in primary dysmenorrhea: a systematic review and meta-analysis. BMC Complement Altern Med. 2019 Jan;19(1):22. 
14. Abaraogu U, Chidinma S, Tabansi-Ochiogu C, Igwe SE. Effectiveness of exercise therapy on pain and quality of life of patients with primary dysmenorrhea: A systematic review with meta-analysis. FTR - Turkiye Fiz Tip ve Rehabil Derg. 2016 Dec 21;62:346-54.

15. Aboushady R, El-saidy T. Effect of Home based Stretching Exercises and Menstrual Care on Primary Dysmenorrhea and Premenstrual Symptoms among Adolescent Girls. In 2016.

16. Chen H-M, Hu H. Randomized Trial of Modified Stretching Exercise Program for Menstrual Low Back Pain. West J Nurs Res. 2018 Mar 13;41:019394591876381.

17. Saleh H, Mowafy H. Stretching or Core Strengthening Exercises for Managing Primary Dysmenorrhea. J Womens Heal Care. 2016 Jan 1;05.

18. Windastiwi W, Pujiastuti W, Mundarti M. Pengaruh Abdominal Stretching Exercise Terhadap Nyeri Dismenore. J KEBIDANAN [Internet]. 2017 Apr 10 [cited 2021 Jul 6];6(12):17. Available from: http://ejournal.poltekkessmg.ac.id/ojs/index.php/jurkeb/article/view/1909

19. Wong. Buku Ajar Keperawatan Pediatrik. Jakarta: EGC; 2008.

20. Potter \& Perry. Buku Ajar Fundamental Keperawatan. Jakarta: EGC; 2010.

21. Judha M. Teori Pengukuran Nyeri dan Nyeri Persaalinan. Yogyakarta: Nuha Medika; 2012.

22. Bustan MN, Seweng A, Achmad E. Abdominal Stretching Exercise in Decreasing Pain of Dysmenorrhea Among Nursing Students. J Phys Conf Ser. 2018 Jun 1;1028:12103.

23. Pratama FY. Latihan Abdominal Stretching Menurunkan Tingkat Nyeri Haid Remaja Putri di Sman 3 Brebes. 2018.

24. Murtiningsih M, Solihah L, Yuniarti S. The Effect of Abdominal Stretching Exercise on Dysmenorrhea in Adolescent Girls. J Matern Care Reprod Heal. 2019;2(3):247-56.

25. Motahari-Tabari N, Shirvani M, Alipour A. Comparison of the Effect of Stretching Exercises and Mefenamic Acid on the Reduction of Pain and Menstruation Characteristics in Primary Dysmenorrhea: A Randomized Clinical Trial. Oman Med J. 2017 Jan 4;32:47-53.

26. Ortiz M, Cortés-Márquez S, Romero-Quezada L, Murguía-Cánovas G, Jaramillo-Díaz A. Effect of a physiotherapy program in women with primary dysmenorrhea. Eur J Obstet Gynecol Reprod Biol. 2015 Aug 17;194:24-9.

27. Barcikowska Z, Rajkowska-Labon E, Grzybowska M, Hansdorfer-Korzon R, Zorena K. Inflammatory Markers in Dysmenorrhea and Therapeutic Options. Int J Environ Res Public Health. 2020 Feb 13;17:1191.

28. Kannan P, Cheung Kwok-Kuen A, Lau Wui-Man B. Does aerobic exercise induced-analgesia occur through hormone and inflammatory cytokine-mediated mechanisms in primary dysmenorrhea? Med Hypotheses. 2018 Dec 1;123. 